Pegem Journal of Education \& Instruction, 4(2), 2014, 01-24

Pegem Eğitim ve Öğretim Dergisi, 4(2), 2014, 01-24

www.pegegog.net

\title{
The Consistency among Curriculum, Textbooks and Placement Tests in Terms of Elementary Biology Education in Turkey
}

\section{Süleyman AKÇAY ${ }^{* a}$}

${ }^{a}$ Süleyman Demirel University, Faculty of Education, Isparta/Turkey

\section{Article Info}

DOI: $10.14527 /$ pegegog.2014.007

Article history:

Received 19 August 2013

Revised 29 December 2013

Accepted 30 January 2014

Keywords:

Curriculum,

Biology education,

Reform in Turkish education,

Science education.

\begin{abstract}
The educational reform movements in Turkey have been accelerating since the 1990s. In connection with this, 5-year compulsory education was changed to 8 years. Following this, primary education curriculum was renewed in 2000 and 2004. The important components of formal education are the curriculum, textbooks and the examinations for entering the next stage of education (such as Secondary Education Placement Examinations (SEPE) and Higher Education Placement Examinations (HEPE) exams). This study investigates the content congruity between primary education second stage (the 6th- 8 grade) curriculum for the science and technology course and the SEPE exams and the textbooks from the perspective of biology. The research found, in consequence, no incongruity between the three elements in general. In SEPE exams (2008-2010), there were no questions on some issues in the textbooks and curriculum which, therefore, can be regarded as inconsistency among curriculum, textbooks and SEPE exams. In the last part of our study, several recommendations towards the innovations of the curriculum have been made for the future.
\end{abstract}

\section{Introduction}

Broadly speaking, educational system is composed of students, the teacher and the curriculum. The innovations in the system of education, however, emerge through updates in the curriculum. The first curriculum in Turkey was designed in 1924 following the foundation of the Republic in 1923 (Gözütok, 2003). Afterwards, modifications were made to the curriculum when needs arose. Until 1997, the compulsory education was 5 years; but it was raised to 8 years with law number 4306 carrying the date 18.08.1997 (Ministry of National Education (MONE, 2011:12). Hence, the first 5 year-part was called the first stage, and the remaining 3-year part was called the second stage. Following this change, modifications were planned to the primary education curriculum in 2000 and in 2004 . In the latest planned curriculum, the name of science course was changed into "science and technology" course.

The reforms conducted in Turkey in recent years have been the subject matter of various research studies (Akınoğlu, 2008; Gözütok, 2003; Ünal, Coştu \& Karataş, 2004). According to Akşit, suggesting that educational reforms should be structural, curriculum is just a part of this structure. The researcher stresses that the fact that Turkish students display achievement below standards in international examinations stands as a basic reason for the revision of the curriculum (Akşit, 2007).

Koç, Işıksal \& Bulut (2007) analyzed the fundamentals of the 2004 primary education curriculum and compared it with the previous one. Although they look quite similar in terms of content, they are extremely different on instructional tools and epistemology.

Dindar and Taneri (2011) made a comparison of the primary education science curricula which had been developed since 1968 in terms of goals, concepts and activities. Although all the curricula up to

\footnotetext{
* Corresponding author: suleymanakcay@gmail.com
} 
2004 have been considered as similar in terms of content, goals and activities, 2004 curriculum is quite different in terms of basic teaching philosophy and instructional tools. Babadoğan and Olkun (2006), on the other hand, analyzed the new primary education curriculum from the perspective of mathematics course. They also stated that 2004 curriculum is adopted more constructivist pedagogies.

Grossman et al. (2007) examined the curricula that were developed in the last 30 years from the perspective of educational policies in Turkey and teacher training. Teacher candidates should be given more qualification and comprehensive education on the curriculum applications. In some other researches, teachers' views as well as the latest primary education curriculum for science and technology course were evaluated. As a result, the new curriculum has been comprehended teachers and teacher candidates are not (Demirbaş, 2008; Özden, 2007). Bulut (2005), analyzed the latest primary education mathematics course curriculum via students' views. Determined that some difficulties appear during the implementation due to lack of physical conditions.

In his study, Özturk (2011) has discussed the new secondary education curriculum in terms of history education. He states that although the new curriculum seems student-centered, the lack of teachers' autonomy has negative influences on the structure. Nakiboğlu (2009) examined secondary school teachers' textbook usage in teaching. According to the research, she stated that teachers in the instructional process do not use the textbooks commonly. The reason for teachers not using textbooks commonly is the incompatibility of HEPE exams and textbooks. In a similar study of us on geometry, Incikabı (2011) states that the compatibility of curriculum, textbooks and SEPE exams is so significant. Today biology is a field with increasing importance in the educational curriculum. Many international examinations such as TIMSS contain a considerable number of biology questions. The percentage of biology questions in science questions is approximately 30\% (Beaton et al. 1996; Martin et al. 2000; Martin et al. 2004; Martin et al 2008). SEPE and HEPE exams also contain a considerable number of science questions. The proportion of biology in the science questions in those tests is about $30 \%$ (SEPE 2010; HEPE 2010).

Uzun, Bütüner \& Yiğit (2000) demonstrated in their research that Turkish students had difficulty in the field of science in TIMSS 1999 and TIMSS 2007 examinations. In TIMSS 1999, Turkey ranked in the 33rd order among 38 countries in science achievement whereas it ranked the 31st among the 49 countries in TIMSS 2007 (Ulusal Rapor, 2011).

Several research studies have analyzed textbooks in terms of content (Abd-El-Khalick, Wters \& Le, 2008; Chiappetta \& Fillman, 2007; de Posada, 1999; Delil, 2006; İrez, 2009; Knain, 2001; Leite, 1999; Lemoni, Stamou \& Stamou, 2011; Niaz, 1998; Rillero, 2010; Roseman, Stern \& Koppal, 2010; Tracana, Carvalho \& Ferreira, 2008; vanEijicg \& Roth, 2008; Wilkinson, 1999; Yang, 2011). Some studies analyzed the way students and teachers used textbook and their views of the books (Güneş, Çelikler \& Gökalp, 2008; Lubben, Campbell, Kasanda, Kapenda, Gaoseb \& Kandjeo-Marenga, 2003; Mulayim \& Soran, 2002). Today, when books are put into electronic media, Kim and Jung (2010), and Sun, Flores \& Tanguma (2012) wrote essays questioning the contributions of e-books to teaching. In this context, textbooks are an indispensable part of formal education in Turkey, as in the entire in world.

National examinations are administered throughout the world as in Turkey in entering a higher level of educational institution or at the end of an educational stage so as to determine the degree of achievement. Bishop (1998) researched the effects of curriculum-based final exams in the United States on students' achievement in mathematics and science. SEPE and HEPE are of the most important of such exams in Turkey. In terms of primary education, SEPE is the subject matter of this study.

İcbay (2005) performed the SWOT (strengths, weaknesses, opportunities, and threats) analysis of the HEPE in Turkey. In consequence, the researcher found many strengths, weaknesses, opportunities and threats. 7 opportunities were described as" the most important opportunities to be taken into consideration", and 7 threats were classified as "the most emphasized and ignorable". The study makes recommendations for a new type of university entrance exam to be applied in Turkey. 
The studies mentioned above show that the exams for the next educational stage and textbooks are important elements in applying the curriculum. In this respect, this study examines biology education in Turkish primary schools in terms of the consistency in the curriculum, textbooks and SEPE exams. The focus of our research questions are as follows;

Biology in terms of primary education in Turkey;

1. What is the distribution of the questions in SEPE exams between 2008-2010?

2. Is there a consistency between the examples in textbooks and time allocated in curriculum?

3. Is there a consistency between the examples in textbooks and the questions in SEPE exams?

4. Is there a consistency between times allocated in curriculum and the questions in SEPE exams?

Twenty years compulsory education in Turkey has started as 4+4+4 in 2012 (Ministry of National Education [MONE], 2012). In this context, curriculums, textbooks and the SEPE exams have been revised since 2012. Our research findings, obtained during this revision are expected to be useful for the next curriculum update period.

\section{Method}

This is a qualitative research in document analysis form (Yıldırım \& Şimşek, 2011). This research examines the coherence holding between primary education second stage science and technology course curriculum, textbooks and the multiple choice science questions in the SEPE test. The $98 \%$ of the institutions conducting compulsory primary education are the state schools in Turkey according to the data obtained at the end of the 2010-2011 academic years (MONE, 2011: 59). With the project started by the Ministry of National Education in 2003, textbooks approved by the ministry are distributed to state schools for free. This study employs the most commonly used science textbooks in the 6th, 7th and 8th grades in state schools with the approval of the Ministry of National Education (see Appendix $E$ for the list of the textbooks used in the study). The 6th grade science textbook received approval for use for 5 years beginning with the 2007-2008 academic year. The textbooks of 7th and 8th grades, however, were published in 2007-2008 and used until 2010. All of them were the books which were published after the configuration of the new 2004 primary education curriculum. The Ministry of Education promulgated the planned new curriculum in 2005. The curriculum was implemented in the 6 th grades in the 2005-2006 academic years, in the 7th grades in the 2006-2007 academic years, and in the 8th grades in the 2007-2008 academic year.

Three types of comparisons are made in this study, which uses binary comparisons: Firstly, the biology exercises in the 6th - 8th grade science and technology textbooks were compared with the proportion of time recommended to be allocated to the biology topics in the primary education Science and Technology Course Curriculum (STCC). Secondly, the biology exercises in the 6th - 8th grade science and technology textbooks were compared with the percentage of biology questions in the SEPE examinations. Apart from that, whether or not questions concerning the topics recently included in the curriculum were asked in the SEPE was also checked. The 2004 STCC and the textbooks in Turkey

The mission of the primary education STCC (grades 6-8) is to raise all the students, regardless of their individual differences, as individuals with science and technology literacy. Seven dimensions were determined in the curriculum for science and technology literacy: 1 . The nature of science and technology, 2. Key science concepts, 3. Scientific process skills, 4. Science-technology-societyenvironment relations, 5. Scientific and technical psychomotor skills, 6. Values forming the essence of science, and 7. Attitudes towards and values concerning science (MONE, 2006: 5).

Seven learning fields were described so as to be able to attain the mission of making all the students' science and technology literate. 4 of the learning fields are: "Living Things and Life", "Matter and change", "Physical Events", and "Earth and the Universe". The learning fields contain the basic science concepts and principles to be facilitated to students. The remaining three learning fields considered 
necessary in the new curriculum are: "science-technology-society-environment relations", "scientific process skills", and "attitudes and values".

Science and technology course is based upon the first four learning fields in terms of content. However, the gains in the following three learning fields were spread into the first four fields in a manner so as to contain skills, attitudes and values (MONE, 2006: 59).

"Living Things and Life", one of the learning fields in the new STCC, was considered as "biology" in this research. The content of the learning fields are detailed as units and headings in the curriculum. The related outcomes that students are required to have, sample activities and the necessary explanations are provided in the curriculum. The outcomes in biology according to the new STCC on the grade basis are presented in Appendix A.

The curriculum is heavily based on constructivist learning approach, and the aim is to make the student uncover the knowledge needed, just like a scientist; rather than passively learning the knowledge. Activities are recommended in the curriculum for this purpose and making the student to make efforts to actively produce and acquire the knowledge (MONE, 2006: 12-17). For these purposes activities are emphasized in the curriculum, and a sample concepts map related with concepts to be acquired is included at the beginning of each topic to set an example for the teacher.

Beginning with the 2007-2008 academic years, MONE changed the structure of the secondary education placement examination, and instead of one examination given at the end of the 8th grade, it was spread into three years. The aim was to reduce the burden that one single examination imposed on students and to spread it into three pieces. With the new practice, those examinations which are administered at the end of the 6th, 7th, and 8th grades are called SBS (SEPE).

The main reason of involving SEPE exams in between 2008-2010 is that the exam was applied to all 6th, 7th and 8th grades between these years. With a decision made in 2003, the Ministry of National Education put the "Free Book Distribution Project in Primary Education" into practice aiming to give students textbooks for free. The project caused changes in the work flow system of the national board of education in terms of the approval of the textbooks. According to the project, a publications board to be established within the body of the national board of education was to examine the textbook drafts and to choose between them and to buy the copyright of the selected books. Those books were then to be published by tender, and the books published were to be sent to schools according to the number of students registered. It was also decided with this project that the books distributed free of charge were to be in use for at least 5 years (Bayrakçı, 2005).

\section{Results}

Table 1 shows the distribution of biology questions in the SEPE examinations in the 2008-2010 periods. The topics are the biology topics included in the new STCC. According to the distribution shown on the grade basis, "circulation system" is the most heavily asked biology topic $(8.3 \%)$ in the 6th grade. This is followed by "Animal Reproduction, Growth and Development", and "Flowering plant reproduction, growth and development". In the 7th grade, on the other hand, "sense organs" by $7.4 \%$, "energy flow in food chain" in the 8 th grade by $12.3 \%$ are the most frequently asked questions. The above mentioned books are in the form of triple sets. Namely, students' book, workbook, and teacher's book. For our research purposes we have only used the students' books.

The new books were prepared according to the constructivist teaching method. For this reason, activities are emphasized in the books as in the curriculum. The activity headings are in the form of questions for rousing interest and for leading to questioning. At the beginning the 6th grade book, the concepts expected to be learnt are presented as a chart. In the 7th and 8th grade books, however, the key concepts are given at the beginning of each topic. The basic questions related to the topics are asked under the title "let's research...". Summaries are given at the end of the units and evaluation 
questions are included. The textbook exercises that we use in this research are those mentioned evaluation questions.

Table 1.

Distribution of Biology Topics in The SEPE Examinations (2008-2010).

\begin{tabular}{|c|c|c|c|c|c|c|}
\hline \multicolumn{2}{|l|}{ 6th Grade } & \multicolumn{2}{|c|}{ 7th Grade } & \multicolumn{2}{|l|}{ 8th Grade } & \multirow[b]{2}{*}{$\begin{array}{c}\text { Total } \\
(\%)\end{array}$} \\
\hline Biology topics & $\begin{array}{c}\text { Proportion } \\
\text { to all (\%) }\end{array}$ & Biology topics & $\begin{array}{l}\text { Proportion } \\
\text { to all (\%) }\end{array}$ & Biology topics & $\begin{array}{l}\text { Proportion } \\
\text { to all (\%) }\end{array}$ & \\
\hline Cell & 2.1 & Digestive system & 5.6 & Mitosis & 3.1 & 14.3 \\
\hline \multicolumn{7}{|l|}{ In humans, } \\
\hline $\begin{array}{l}\text { Reproduction, Growth } \\
\text { and Development }\end{array}$ & 4.2 & Urinary System & 5.6 & Heredity & 6.2 & 16 \\
\hline Animal Reproduction, & & Supervisory and & & & & \\
\hline Growth and & 6.3 & Regulatory & 3.7 & Meiosis & - & 10 \\
\hline Development & & Systems & & & & \\
\hline $\begin{array}{l}\text { Flowering plant } \\
\text { reproduction, growth } \\
\text { and development }\end{array}$ & 6.3 & Sense Organs & 7.4 & $\begin{array}{r}\text { DNA and the Genetic } \\
\text { Code }\end{array}$ & 1.5 & 15.2 \\
\hline $\begin{array}{l}\text { Support and } \\
\text { Movement System }\end{array}$ & 4.2 & Ecosystems & 5.6 & $\begin{array}{r}\text { Adaptation and } \\
\text { Evolution }\end{array}$ & 4.6 & 14.4 \\
\hline Respiratory System & - & $\begin{array}{r}\text { Biodiversity in } \\
\text { Turkey } \\
\text { Environmental } \\
\text { Problems and* }\end{array}$ & - & $\begin{array}{r}\text { Food Chain Energy } \\
\text { Flow }\end{array}$ & 12.3 & 12.3 \\
\hline \multirow[t]{3}{*}{$\begin{array}{l}\text { The Circulatory } \\
\text { System }\end{array}$} & 8.3 & $\begin{array}{r}\text { Effects of our } \\
\text { country and the } \\
\text { world }\end{array}$ & 5.6 & Matter Cycles & 1.5 & 15.4 \\
\hline & & & & Recycling & 1.5 & 1.5 \\
\hline & & & & $\begin{array}{l}\text { Renewable and } \\
\text { Nonrenewable } \\
\text { Energy Sources }\end{array}$ & 1.5 & 1.5 \\
\hline Total (\%): & 34.9 & & 33.5 & & 30.7 & \\
\hline
\end{tabular}

Based on http://oges.meb.gov.tr/sbs/

\section{Curricula versus Textbooks}

Table 2 shows a comparison of the proportion of time allocated to the four main learning fields recommended in the new STCC with the percentage of textbook exercises. Accordingly, it is clear that considerable amount of time is allocated to biology in the curriculum. The time allocated is $6.6 \%$ more than the book exercises for the 6 th grade; yet it is $2.4 \%$ and $1.6 \%$ less for the 7 th and 8 th grades.

Appendix $B$ shows the time allocation recommended in the curriculum for the biology topics as well as the percentages of exercises in the science and technology books (the 6th, 7th, and 8th grades). In the overall proportions the recommended time is $7.1 \%$ more than the book exercises for the 6th grade while it is $2.5 \%$ and $1.6 \%$ less for the 7 th and 8 th grades, respectively. There are no big differences in terms of topics. Yet, in the topic of "environmental problems and effect of our country and world", a considerable difference by $5.6 \%$ is remarkable against the recommended time allocation in the curriculum. 
Table 2.

Percentage Coverage of Each Learning Area in The Science and Technology Curriculum and Science and Technology Textbooks by Grade Level During 2008 and 2010 (Academic Years).

\begin{tabular}{|c|c|c|c|c|c|c|}
\hline \multirow[b]{2}{*}{ Learning area } & \multicolumn{2}{|c|}{6 th grade } & \multicolumn{2}{|c|}{ 7th grade } & \multicolumn{2}{|c|}{ 8th grade } \\
\hline & $\begin{array}{r}\text { Time } \\
\text { allocation }\end{array}$ & $\begin{array}{l}\text { Textbook } \\
\text { examples }\end{array}$ & $\begin{array}{r}\text { Time } \\
\text { allocation }\end{array}$ & $\begin{array}{l}\text { Textbook } \\
\text { examples }\end{array}$ & $\begin{array}{r}\text { Time } \\
\text { allocation }\end{array}$ & $\begin{array}{l}\text { Textbook } \\
\text { examples }\end{array}$ \\
\hline Living Things and Life* & 30.4 & 23.8 & 32 & 34.4 & 27.8 & 29.4 \\
\hline Matter and Change & 30.5 & 23.8 & 25 & 14 & 34.7 & 23.5 \\
\hline Physical Events & 29.4 & 34 & 33.3 & 38.4 & 29.2 & 34 \\
\hline Earth and the Universe & 9.7 & 18.4 & 9.7 & 13.2 & 8.3 & 13.1 \\
\hline
\end{tabular}

* This topic is considered "Biology"

\section{Textbooks versus Examinations}

Table 3 presents a comparison of the proportion of exercises in the textbooks for the four main learning fields and the proportion of questions asked in the SEPE. According to the table, a considerable number of biology (Living Things and Life) questions are asked in the SEPE. A remarkable difference is available by $7.4 \%$ for the 6 th grade in favour of the exam questions. Similar percentages are available for the 7 th and 8 th grades.

Table 3.

Percentage Coverage of Learning Areas in Science and Technology Textbooks and of the Science Sections of the SEPE Examinations by Grade Level During 2008 and 2010 (Academic Years).

\begin{tabular}{lrrrrrr}
\hline & \multicolumn{2}{c}{ 6th grade } & \multicolumn{2}{c}{ 7th grade } & \multicolumn{2}{c}{ 8th grade } \\
\hline \multirow{2}{*}{ Learning area } & $\begin{array}{r}\text { Textbook } \\
\text { examples }\end{array}$ & $\begin{array}{r}\text { Examination } \\
\text { Questions }\end{array}$ & $\begin{array}{r}\text { Textbook } \\
\text { examples }\end{array}$ & $\begin{array}{r}\text { Examination } \\
\text { Questions }\end{array}$ & $\begin{array}{r}\text { Textbook } \\
\text { examples }\end{array}$ & $\begin{array}{r}\text { Examination } \\
\text { Questions }\end{array}$ \\
\hline Living Things and Life* & 23.8 & 31.2 & 34.4 & 33.3 & 29.4 & 33.8 \\
Matter and Change & 23.8 & 31.2 & 14 & 27.8 & 23.5 & 27.7 \\
Physical Events & 34 & 31.3 & 38.4 & 33.3 & 34 & 35.4 \\
Earth and the Universe & 18.4 & 6.3 & 13.2 & 5.6 & 13.1 & 3.1 \\
\hline
\end{tabular}

* This topic is considered "Biology"

Appendix $C$ shows the proportion of textbook exercises for biology topics and the proportion of questions asked in the SEPE according to grade levels. In general, there are no significant differences between the two. For the 6th grade, $6.8 \%$ difference is in favour of SEPE questions. For the 7th grade, $1.1 \%$ difference is in favour of the textbook exercises. For the 8 th grade, $4.4 \%$ difference is in favour of SEPE questions. In 11 topics the percentage of textbook exercises is higher, and in 11 topics the percentage of SEPE questions is higher. In a topic, however, (heredity) we see equivalence. Moreover, no questions were asked about 3 topics. They are "respiratory system" for the 6th grade, "biodiversity in Turkey" for the 7th grade, and "meiosis" for the 8th grade. Especially the fact that no questions are asked in the SEPE about the "respiratory system" for the 6th grade, which contains a serious amount of exercises (43.3\%) can be considered as incongruity.

\section{Curricula versus Examinations}

Table 4 compares the percentage of the questions asked in the SEPE about the four main fields of learning stated in the curriculum with the percentage of recommended time allocation. It is clear that the rate of SEPE questions is slightly more than the rate of recommended time. 
Table 4.

Percentage Coverage of Each Learning Area in The Science and Technology Curriculum and Questions SEPE Examinations (During 2008 - 2010 Academic Years).

\begin{tabular}{lrrrrrr}
\hline & \multicolumn{2}{c}{ 6th grade } & \multicolumn{2}{c}{ 7th grade } & \multicolumn{2}{c}{ 8th grade } \\
\hline Learning area & $\begin{array}{r}\text { Time } \\
\text { allocation }\end{array}$ & $\begin{array}{r}\text { Examination } \\
\text { Questions }\end{array}$ & $\begin{array}{r}\text { Time } \\
\text { allocation }\end{array}$ & $\begin{array}{r}\text { Examination } \\
\text { Questions }\end{array}$ & $\begin{array}{r}\text { Time } \\
\text { allocation }\end{array}$ & $\begin{array}{r}\text { Examination } \\
\text { Questions }\end{array}$ \\
\hline Living Things and Life* & 30.4 & 31.2 & 32 & 33.3 & 27.9 & 33.8 \\
Matter and Change & 30.5 & 31.2 & 25 & 27.8 & 34.7 & 27.7 \\
Physical Events & 29.4 & 31.3 & 33.3 & 33.3 & 29.1 & 35.4 \\
Earth and the Universe & 9.7 & 6.3 & 9.7 & 5.6 & 8.3 & 3.1 \\
\hline
\end{tabular}

* This topic is considered "Biology"

Appendix $D$ gives the proportion of time allocation recommended in the curriculum and the proportion of questions asked in the SEPE in details in terms of biology topics. In the tables provided according to grade levels, the proportion of SEPE questions is found to be higher by $0.7 \%, 1.4 \%$ and $6 \%$ for the 6th, 7th, and 8th grades, respectively. The reverse is also true for some topics. In the topic of "cell" for the 6th grade $2.1 \%$ difference in favour of the recommended time is available whereas $0.4 \%$ difference is available in the topic of "support and movement system". For the 8th grade, in the topic of DNA and genetic code", $0.2 \%$ difference and in the topic of "renewable and unrenewable sources of energy" $1.3 \%$ difference is available.

Table 5.

Incompatible Biology Content.

\begin{tabular}{llrrr}
\hline \multirow{2}{*}{ Grade } & \multirow{2}{*}{ Topics } & \multicolumn{3}{c}{ Coverage (\%) } \\
\cline { 3 - 5 } & & Textbook & Curriculum & Test \\
\hline 6th & Respiratory system & 3.4 & 4.6 & 0 \\
7th & Biodiversity in Turkey & 2.6 & 3.7 & 0 \\
8th & Meiosis & 2 & 3.5 & 0 \\
\hline
\end{tabular}

Various differences are available between the three dimensions (the recommended time allocation in the curriculum, the SEPE questions, and textbook exercises) that are included in our research. In SEPE exams, no questions have been included in three topics: Respiratory system, Biodiversity in Turkey and Meiosis. Despite the fact that these three topics are available in considerable amounts in the new curriculum and in the textbooks, no questions are asked in the SEPE, which can be considered as an incongruity.

Questions are asked at a high proportion (12.3\%) in the SEPE about "energy flow in food chain", where photosynthesis is described. Table 2 demonstrates that the time allocation recommended in the curriculum for biology and the percentage of textbook exercises occupy a significant place in the total. The percentages of recommended time allocation and of textbook exercises do not differ significantly on grade basis. According to Table 3, the proportion of textbook exercises in biology field and of the questions in the SEPE is almost the same for the 7th and 8th grades. However, for the 6th grade, a difference of $7.4 \%$ is available. Table 4 , on the other hand, compares the time recommended in the curriculum and the SEPE questions, and shows that there are no serious differences in distribution in all the grade levels. 


\section{Discussion, Conclusion \& Implementation}

This research examined the coherence holding between primary education curriculum, textbooks and placement tests from the perspective of biology. The basic sources used were the primary education second stage (6th, 7th, 8th grades) curriculum for science and technology course. Textbooks of science and technology, and secondary education entrance examinations.

This research is restricted to the national curriculum, national textbooks and the secondary education entrance examination documents. The differing uses of those documents were excluded from analyses. For instance, the activities included in the curriculum for the primary education second stage science and technology course might not have been used by science teachers in the application or might have been used in different ways. The latest change of curriculum in Turkey also made changes in teacher training necessary. Yet, research demonstrates that teachers are not sufficiently knowledgeable about the new curriculum (Özden, 2007; Tekbıyık \& Akdeniz, 2008), or they do not employ it in application (Karaer, 2006). They also encounter problems related with infrastructure and time (Aydın, 2007; Bulut, 2005). In consequence, problems encountered in implementing the curriculum and the lack of teacher education is the elements reducing the efficiency of the curriculum reform.

Several research studies have been performed in recent years on photosynthesis (Brown \& Schwartz, 2009; Cañal, 1999; Griffard \& Wandersee, 2001; Käpylä, Heikkinen \& Asunta, 2009; Kral, Lott \& Wymer, 2009; Lin \& Hu, 2003; Marmaroti \& Galanopoulou, 2006; Piper \& Shaw, 2010; Yenilmez \& Tekkaya, 2006). This may be considered as the indicator of importance attached to the teaching of this topic all over the world. The fact that considerable quantity of questions are asked in the SEPE (12.3\%) about photosynthesis also shows the importance attached to the issue in Turkey. The subject of meiosis in the 8th grades is crucial in order to promote basis for the subjects of heredity in the curriculum of secondary education. For this reason, it can be accepted as a deficiency of having no question about meiosis during 2008-2010 SEPE exams.

This research analyzed biology education in Turkey following the latest reform to primary education curriculum in terms of curriculum, textbooks and national examinations. Mostly, these three elements are compatible. However, Turkish students display low level of science achievement in national and international examinations (such as TIMSS and PISA) (Ulusal Rapor, 2011). Therefore, it seems that it is necessary to research the targeted outcomes and the inadequacies of educational activities in application or the causes for outcomes failing to be reflected into achievement. Furthermore, it would be beneficial to examine the teachers' books and students' workbooks by researchers, which we did not include in our research. 


\section{Appendices}

\section{Appendix A}

The latest version of the learning outcomes defined for the biology is as in the following: At the 6th grade level, students are expected to (MONE, 2006):

- observe an animal or a plant cell through a microscope and to draw it,

- show the basic parts of a cell on a plate or a model, and to describe its tasks,

- list the similarities and differences between animal and plant cells following the observations,

- emphasize that cells display life properties that an organism has,

- give examples for different types of cells,

- explain that tissues are formed with the gathering of cells with similar structures and properties to perform the same function,

- explain the cell-tissue-organ-system-organism relation,

- recognize that sperms and eggs facilitating reproduction are the cells which acquire different structures according to their tasks,

- show the structures and organs enabling reproduction in humans on a plate, model or diagram,

- state that reproduction organs form the germ cells necessary for the continuation of generations,

- comment on the relationship between sperms/eggs/oosperm/embryo,

- research and present what a prospective mother should be careful about so that an embryo can develop in a healthy way,

- interpret the changing age-size-mass relation due to growing up,

- Label the developmental periods of humans in consequence of observations and to list the remarkable characteristics,

- List the physical and psychological changes arising in transition from childhood into adolescence,

- Share his/her physical and psychological changes with parents/peers/personal development experts,

- Recognize that adolescence period is a natural part of human life,

- Recognize the things to be done in order to pass through adolescence in a healthy way,

- Recognize the importance of social organizations where growing up, development and adolescence are researched, discussed and shared, and be eager to participate in those organizations,

- Explain through examples that animals have a life cycle,

- Recognize that animals have different forms of reproduction,

- Explain the causes for differences in baby caring between animal groups,

- Give examples for animals experiencing mutation in developmental periods,

- Show and draw the parts of a flower,

- Show the parts of a flower on a model, plate, or diagram, and describe their tasks,

- State the factors facilitating pollination in flowery plants,

- Explain the insemination in flowery plants,

- Explain where the seed and the fruit is formed on a model of plant,

- Discuss the reasons why plants form a great number of seeds,

- Give examples for the ways seeds spread,

- Present with examples that many fruits and seeds are a source of food for animals and humans,

- Recognize that products obtained from plants vary in parallel to technological development,

- Show through examples that plants have a life cycle,

- Record and interpret the data obtained through observations with controlled experiments on factors influencing germination,

- Observe what factors are necessary for growing by doing experiments,

- Explain organic agriculture,

- Recognize the importance of organic agriculture for humanity, 
- Describe the parts and tasks of the parts of the bone,

- Describe the importance of cartilage in the skeleton,

- Classify the joints as abarthrosis, amphiarthrosis and synarthrosis and give examples,

- Classify the muscles as smooth, skeletal, and cardic muscles, and give examples,

- Describe the importance of muscles working adversely in movement,

- Question the positive and negative behaviors influential in the health of support and movement system,

- Exemplify the contributions of technological advances to the support and movement system,

- show the structures and organs constituting the circulatory system on a model, plate and diagram,

- explain the structure and function of heart,

- explain the types and tasks of blood vessels,

- explain the structure and tasks of blood,

- show and explain systemic circulation and pulmonary circulation on a diagram,

- explain that humans have different blood groups,

- recognize the importance of blood donation for human body and for society, and urge the people in the vicinity for this,

- explain that lymph is the element of circulatory system and describe its importance,

- give recommendations as to protect the cardiovascular health, and be careful about this,

- give examples for the use of technological developments in the treatment of diseases concerning the circulatory system,

- recognize that the body has natural hurdles against harmful microorganisms (microbes),

- explain that immunity protects the body against harmful microorganisms,

- explain the general characteristics of viruses and bacteria, and give examples from daily life for diseases caused by them,

- explain the importance of vaccination, serum and medicine, and relate them to technological development,

- recognize the effects of unconscious use of medicine and display positive attitudes in terms of correct use of medicine,

- show the structures, and organs constituting the respiratory system on a model, plate and diagram, and explain their tasks,

- explain the structure of lungs and show the gas exchange between alveol and capillary vessels,

- design a model demonstrating the inhaling exhaling mechanism,

- discuss the positive-negative effects of technological developments on the respiratory system,

- give practical recommendations on protecting the health of respiratory system.

At the 7 th grade level, students are expected to:

- show the structures and organs constituting the digestive system on a model, plate and diagram,

- guess that food should undergo a change in order to be useful for the body,

- explain that food should be physically and chemically digested so as to enter the blood, explain the function of enzymes in chemical digestion,

- explain the tasks of lungs and pancreas in digestion,

- explain the transition of digested food into blood through intestines,

- summaries the factors with negative influences in the health of digestive system,

- show the structures and organs constituting the excretory system on a model, plate and/or diagram,

- explain the duty and importance of the kidneys in the excretory system,

- recognize the precautions to be taken to protect the health of the excretory system,

- give examples for technological developments used in the treatment of some kidney diseases, 
- explain that the supervisory and regulatory system enable the systems in the body to operate regularly and in coordination,

- show the parts of nervous system on a model, plate and diagram,

- explain the tasks of the parts of nervous system,

- design experiments to observe reflexes,

- show the endocrine glands on a model, plate and/or diagram and explain their tasks,

- recognize the roles of the sense organs in perceiving the stimuli in the environment,

- explain the structure of sense organs on figures and/or models,

- explain the types of stimuli that sense organs perceive and how they respond to the stimuli,

- show the relations between smelling and tasting through experiments,

- give examples for malfunctions of sense organs and for the use of technology in fixing the malfunctions,

- give examples for precautions to be taken for protecting the health of sense organs from daily life,

- put oneself in the place of someone with seeing or hearing defects and try to understand them,

- give examples for the working of all the systems in the body altogether and in coordination,

- research the effects of substances causing addiction on the systems and present them,

- emphasize the importance of organ donation,

- appreciate the people continuing their work in the society despite their health problems and show them understanding,

- explain the concepts of species, habitat and population with examples,

- explain the mutual relations of living organisms in an ecosystem as well as their relations with non-living factors,

- make guesses about living things that may be available in differing ecosystems,

- compare the ecosystems in terms of variation of living things and climate properties,

- recognize the biological variation in ecosystems and emphasize its importance,

- give examples for species in danger of extinction in our country and in the world,

- make recommendations on how to protect the plants and animals under the risk of extinction in our country and in the world,

- show affection to the plants and animals in the environment,

- gather information on one of the environmental problems available in the world and in our country, and discuss the consequences,

- make inferences about how a global environmental problem can influence our country,

- recommend coordination-based solutions for the environmental problems in our country and in the world, and participate in social events for this,

- give examples for Ataturk's practices related with environmental love,

At the 8th grade level, students are expected to:

- explain that growing and reproduction occur in living things through cell division,

- describe mitosis as a number of phases beginning with nuclear fission and coming after another; recognize the importance of chromosomes in mitosis and point out that the number of chromosomes may differ in different species,

- explain the importance of mitosis in living things and relate it to growing and reproduction,

- compare the similarities and differences between him/her and his/her parents by observation,

- infer that babies are similar to their parents, but that they are not the same,

- analyses the importance of Mendel's work in heredity,

- gather information on the concept of genes, and recognize dominant and recessive genes,

- comprehend the relation between phenotype and genotype,

- solve problems about the heredity of one single character,

- give examples for some genetic diseases common in humans, 
- research the negative consequences of kin marriages and discuss them,

- give examples for the effects of scientific and technological advances on the treatment of genetic diseases,

- make the inference that reproductive cells are formed through meiosis,

- recognize the importance of meiosis for living things,

- list the properties distinguishing meiosis from mitosis,

- recognize that hereditary knowledge is carried by genes,

- show the structure of DNA on a diagram and produce a simple model of DNA,

- show how DNA synchronize itself by doing a simple model,

- make associations between the concepts of nucleotide, gene, and DNA,

- describe mutation and modification and explain the difference through examples,

- give brief information on the present day applications of genetic engineering and discuss them,

- guess the implications of developments in genetic engineering for humanity,

- appreciate the positive consequences of developments in genetic engineering,

- gather information on the importance of biotechnological work in our life and give relevant examples for working fields,

- explain the adaptation of living things into the habitat with examples,

- explain why different organisms in the same habitat develop similar adaptations,

- give examples for the fact that the adaptation of living things can contribute to biological variation and to evolution,

- give examples for different views of evolution,

- make the inference that producers are at the beginning of the food chain,

- explain that producers photosynthesize and thus produce simple sugar and oxygen,

- give a list of things necessary for photosynthesis,

- observe the necessity of light in photosynthesis by doing experiments,

- describe photosynthesis with an equation,

- discuss the importance of photosynthesis for living things,

- explain that producers transform photosynthesis and the solar energy into usable energy,

- state that living things need energy to live,

- explain that consumers in the food chain meet their energy needs through producers,

- discuss the importance of respiration for living things,

- show the products formed in consequence of respiration with oxygen through experiments,

- guess the equation for respiration with oxygen through observations,

- explain that some living organisms provide the energy necessary for living without using oxygen,

- give examples for anaerobic respiration from daily life,

- compare the equation of respiration with oxygen with the equation of photosynthesis and explain the relations between the two,

- explain the relations between the producers and the consumers in terms of nutrition and energy flow,

- explain the matter cycles in parallel to the energy flow in the food chain,

- give examples for renewable and unrenewable sources of energy,

- research the use of renewable and unrenewable sources of energy and present the findings,

- emphasize the importance of using renewable sources of energy,

- make a design which may serve as an example for the use of renewable sources of energy,

- explain what recycling is, and its necessity with examples,

- put recycling applications into effect in the environment of living. 


\section{Appendix B}

Percentage coverage of biology learning area in science and technology curriculum and science and technology textbooks by grade level during the post-reform period

Table 6.

6th Grade Biology Coverage in Curriculum and Textbooks (\%).

\begin{tabular}{lrr}
\hline Topics & TA & TE \\
\hline Cell & 4.2 & 2.88 \\
In humans. Reproduction. Growth and Development & 4.2 & 4.33 \\
Animal Reproduction. Growth and Development & 4.2 & 2.88 \\
Flowering plant reproduction. growth and development & 4.2 & 4.33 \\
Support and Movement System & 4.6 & 2.40 \\
Respiratory System & 4.6 & 4.33 \\
The Circulatory System & 4.6 & 3.37 \\
Total & 30.6 & 24.5 \\
\hline
\end{tabular}

Table 7.

7th Grade Biology Coverage in Curriculum and Textbooks (\%).

\begin{tabular}{lrr}
\hline Topics & TA & TE \\
\hline Digestive system & 5.2 & 4.0 \\
Urinary System & 5.2 & 2.6 \\
Supervisory and Regulatory Systems & 5.2 & 6.0 \\
Sense Organs & 5.2 & 2.6 \\
Ecosystems & 3.7 & 7.3 \\
Biodiversity in Turkey & 3.7 & 2.6 \\
Environmental Problems and Effects of our country and the world & 3.7 & 9.3 \\
Total & 31.9 & 34.4 \\
\hline
\end{tabular}

Table 8.

8th Grade Biology Coverage in Curriculum and Textbooks (\%).

\begin{tabular}{lrr}
\hline Topics & TA & TE \\
\hline Mitosis & 3.3 & 1.3 \\
Heredity & 3.3 & 4.6 \\
Meiosis & 3.3 & 2.0 \\
DNA and the Genetic Code & 3.3 & 3.9 \\
Adaptation and Evolution & 3.3 & 3.9 \\
Food Chain Energy Flow & 2.8 & 6.5 \\
Matter Cycles & 2.8 & 3.3 \\
Recycling & 2.8 & 1.3 \\
Renewable and Nonrenewable Energy Sources & 2.8 & 2.6 \\
Total & 27.8 & 29.4 \\
\hline
\end{tabular}

TA: Time allocation. TE: Textbook examples 


\section{Appendix C}

Percent coverage of biology learning area in science and technology textbooks and the SEPE examinations by grade level during the post-reform period.

Table 9.

6th Grade Biology Coverage in Textbooks and SEPE Examinations (\%).

\begin{tabular}{lrr}
\hline Topics & TE & EQ \\
\hline Cell & 2.88 & 2.1 \\
In humans. Reproduction. Growth and Development & 4.33 & 4.2 \\
Animal Reproduction. Growth and Development & 2.88 & 6.3 \\
Flowering plant reproduction. growth and development & 4.33 & 6.3 \\
Support and Movement System & 2.40 & 4.2 \\
Respiratory System & 4.33 & 0.0 \\
The Circulatory System & 3.37 & 8.3 \\
Total & 24.5 & 31.3 \\
\hline
\end{tabular}

Table 10.

7th Grade Biology Coverage in Textbooks and SEPE Examinations (\%).

\begin{tabular}{lrr}
\hline Topics & TE & EQ \\
\hline Digestive system & 4.0 & 5.6 \\
Urinary System & 2.6 & 5.6 \\
Supervisory and Regulatory Systems & 6.0 & 5.6 \\
Sense Organs & 2.6 & 5.6 \\
Ecosystems & 7.3 & 5.6 \\
Biodiversity in Turkey & 2.6 & 0.0 \\
Environmental Problems and Effects of our country and the world & 9.3 & 5.6 \\
Total & 34.4 & 33.3 \\
\hline
\end{tabular}

Table 11.

8th Grade Biology Coverage in Textbooks and SEPE Examinations (\%).

\begin{tabular}{lrr}
\hline Topics & TE & EQ \\
\hline Mitosis & 1.3 & 4.6 \\
Heredity & 4.6 & 4.6 \\
Meiosis & 2.0 & 0.0 \\
DNA and the Genetic Code & 3.9 & 3.1 \\
Adaptation and Evolution & 3.9 & 6.2 \\
Food Chain Energy Flow & 6.5 & 4.6 \\
Matter Cycles & 3.3 & 6.2 \\
Recycling & 1.3 & 3.1 \\
Renewable and Nonrenewable Energy Sources & 2.6 & 1.5 \\
Total & 29.4 & 33.8 \\
\hline
\end{tabular}

TE: Textbook examples. EQ: Examination questions 


\section{Appendix D}

Percentage coverage of biology learning area in science and technology curriculum and the SEPE examinations by grade level during the post-reform period.

Table 12.

6th Grade Biology Coverage in Curriculum and SEPE Examinations (\%).

\begin{tabular}{lrr}
\hline Topics & TA & EQ \\
\hline Cell & 4.2 & 2.1 \\
In humans. Reproduction. Growth and Development & 4.2 & 4.2 \\
Animal Reproduction. Growth and Development & 4.2 & 6.3 \\
Flowering plant reproduction. growth and development & 4.2 & 6.3 \\
Support and Movement System & 4.6 & 4.2 \\
Respiratory System & 4.6 & 0.0 \\
The Circulatory System & 4.6 & 8.3 \\
Total & 30.6 & 31.3 \\
\hline
\end{tabular}

Table 13.

7th Grade Biology Coverage in Curriculum and SEPE Examinations (\%).

\begin{tabular}{lrr}
\hline Topics & TA & EQ \\
\hline Digestive system & 5.2 & 5.6 \\
Urinary System & 5.2 & 5.6 \\
Supervisory and Regulatory Systems & 5.2 & 5.6 \\
Sense Organs & 5.2 & 5.6 \\
Ecosystems & 3.7 & 5.6 \\
Biodiversity in Turkey & 3.7 & 0.0 \\
Environmental Problems and Effects of our country and the world & 3.7 & 5.6 \\
Total & 31.9 & 33.3 \\
\hline
\end{tabular}

Table 14.

8th Grade Biology Coverage In Curriculum and SEPE Examinations (\%).

\begin{tabular}{lrr}
\hline Topics & TA & EQ \\
\hline Mitosis & 3.3 & 4.6 \\
Heredity & 3.3 & 4.6 \\
Meiosis & 3.3 & 0.0 \\
DNA and the Genetic Code & 3.3 & 3.1 \\
Adaptation and Evolution & 3.3 & 6.2 \\
Food Chain Energy Flow & 2.8 & 4.6 \\
Matter Cycles & 2.8 & 6.2 \\
Recycling & 2.8 & 3.1 \\
Renewable and Nonrenewable Energy Sources & 2.8 & 1.5 \\
Total & 27.8 & 33.8 \\
\hline
\end{tabular}

TA: Time allocation. EQ: Examination questions

\section{Appendix E}

List of textbooks used in this study:

Korkmaz, H., Tatar, N., Kıray, S.A. \& Kibar, G. (2010). Ilköğretim fen ve teknoloji 6 ders kitabı (Science 6). Ankara: Tuna Matbaacılık.

Tunç, T., Bağcı, N., Yörük, N., Köroğlu, N.G., Altınoğlu, U.Ç., Başdağ, G., Keles, O., İpek, I. \& Bakar, E. (2010). Illköğretim fen ve teknoloji 7 ders kitabı (Science 7). İstanbul: Bediralp Matbaacılık.

Tunç, T., Bakar, E., Başdağ, G., İpek, I., Bağcl, N., Köroğlu, N.G., Yörük, N. \& Keles, O. (2010). Illköğretim fen ve teknoloji 8 ders kitabı (Science 8). İstanbul: Bediralp Matbaacılık. 
Pegem Journal of Education \& Instruction, 4(2), 2014, 01-24

Pegem Eğitim ve Öğretim Dergisi, 4(2), 2014, 01-24

www.pegegog.net

Türkiyedeki İlköğretim Biyoloji Eğitimi Açısından Program, Ders Kitapları ve Yerleştirme Sınavları Arasındaki Uyum

\section{Süleyman AKÇAY ${ }^{\mathrm{a}^{*}}$}

${ }^{a}$ Süleyman Demirel Üniversitesi, Isparta/Türkiye

Makale Bilgisi

DOI: $10.14527 /$ pegegog.2014.007

Makale geçmişi:

Geliş 19 Ağustos 2013

Düzeltme 29 Aralık 2013

Kabul $\quad 30$ Ocak 2014

Anahtar kelimeler:

Program,

Biyoloji eğitimi,

Türk eğitim sisteminde reform,

Fen eğitimi.
Öz

Türkiye'de eğitimde reform hareketi 1990lardan sonra hız kazanmıştır. Bu doğrultuda zorunlu eğitim 5 yıldan 8 yıla çıkartılmıştır. Bu değişimlerin sonucu olarak, ilköğretim programında 2000 ve 2004 yıllarında yenilemeler yapılmıştır. Resmi eğitimde program, ders kitapları ve bir üst öğrenim kademesine geçiş sınavları önemli bileşenlerdir. Araştırmamızda, ilköğretim biyoloji eğitimi (6, 7 ve 8 . sınıflar) açısından program, ders kitapları ve Seviye Belirleme Sınavları (SBS) arasındaki içerik uyumu incelenmiştir. Sonuç olarak bu üç öğe arasında genel manada bir uyum olduğu söylenebilir. Ancak, 2008-2010 yılları arasında bazı biyoloji konularında hiç soru çıkmaması bir uyumsuzluk oluşturmaktadır. Çalışmamızın son kısmında ise, gelecekte yapılabilecek program değişiklikleri veya güncellemelerine yönelik bazı öneriler sunulmuştur.

\section{Giriş}

Eğitim sistemi genel anlamda öğrenci, öğretmen ve programdan (müfredat) oluşur. Eğitim sistemindeki yenilikler ise programdaki güncellemeler ile meydana gelir. Türkiye'de 1923 yılında cumhuriyetin kurulmasından sonra ilk program 1924 yılında ilköğretim programı olarak hazırlanmıştır (Gözütok, 2008). Daha sonraları ihtiyaçlar bağlamında çeşitli zamanlarda program yenilemeleri yapılmıştır. Türkiye'de 1997 yılına kadar zorunlu eğitim 5 yıl iken; 18.08 .1997 tarih 4306 sayılı yasa ile 8 yıllık zorunlu eğitime geçilmiştir (MEB, 2011: 12) Bu bağlamda ilk 5 yıla ilköğretim birinci kademe, devamındaki 3 yıla ilköğretim ikinci kademe denilmiştir. Bu değişikliğin devamında ilköğretim programına 2000 ve 2004 yıllarında değişiklikler planlanmıştır. Son planlanan ilköğretim programında ise fen bilgisi olan fen dersinin adı "fen ve teknoloji" olarak değiştirilmiştir.

Türkiye'de son yıllarda yapılan eğitim reformları çeşitli araştırmaların konusu olmuştur (Akınoğlu, 2008; Gözütok, 2003; Ünal, Coştu ve Karataş, 2004) Eğitim reformlarının yapısal olması gerektiğini söyleyen Akşit, öğretim programının bu yapının sadece bir parçası olduğunu belirtmiştir. Türk öğrencilerin uluslararası sınavlarda ortalamanın altında başarı sergilemelerinin yeni program revizyonları için temel bir gerekçe olduğunu vurgulamıştır (Akşit, 2007).

Koç vd. (2007), 2004 ilköğretim programının temellerini incelemiş ve bir önceki ile karşılaştırmıştır. Sonucunda ise, içerik açısından 2004 programının bir önceki program ile çok büyük benzerlik göstermesine rağmen, epistemolojik açıdan ve öğretim yöntemleri açısından oldukça farklı olduğunu belirtmektedir. Dindar ve Taneri (2011), 1968 yılından bu yana geliştirilen ilköğretim fen programlarını amaç, kavram ve etkinlikler yönünden kıyaslamıştır. 2004 programına kadar ki tüm programların içerik, amaçlar ve aktiviteler açısından oldukça benzer olmasına rağmen 2004 programının temel öğretim felsefesi ve öğretim yöntemleri açısından farklılığına vurgu yapmışlardır. Babadoğan ve Olkun (2006),

*Yazar: suleymanakcay@gmail.com 
yeni ilköğretim programını matematik dersi açısından incelemiş ve sonucunda; 2004 programının yapısalcı öğretim tekniklerini benimsediğini belirtmişlerdir.

Grosman (2007), Türkiye'de eğitim politikaları ve öğretmen eğitimi açısından son 30 yıl içerisinde geliştirilen programları incelemiştir. Çalışmasının sonuç kısmında, öğretmen adaylarının program uygulamaları ve öğretimde kullanımı açısından niteliğin artırılması gerektiğini ifade etmektedir. Bazı araştırmalarda ise öğretmen görüşleri ile son ilköğretim fen ve teknoloji programı değerlendirilmiştir (Özden, 2007; Demirbaş, 2008). Bulut (2005) ise, öğrenci görüşleri yoluyla son geliştirilen ilköğretim matematik programını değerlendirmiş ve programın uygulamasında fiziksel koşulların yetersizliğinden kaynaklanan bazı sorunlara dikkati çekmiştir.

Birçok araştırmada okul kitapları içerikleri açısından incelenmiştir (Abd-El-Khalick, Wters ve Le, 2008; Chiappetta ve Fillman, 2007; de Posada, 1999; Delil, 2006; İrez, 2009; Knain, 2001; Leite, 1999; Lemoni, Stamou ve Stamou, 2011; Niaz, 1998; Rillero, 2010; Roseman, Stern ve Koppal, 2010; Tracana, Carvalho ve Ferreira, 2008; van Eijicg ve Roth, 2008; Wilkinson, 1999; Yang, 2011). Bazı makalelerde ise öğrenci ve öğretmenlerin okul kitaplarını nasıl kullandıkları ve bunlar hakkındaki görüşleri incelenmiştir (Güneş, Çelikler ve Gökalp, 2008; Lubben, Campbell, Kasanda, Kapenda, Gaoseb ve Kandjeo-Marenga, 2003; Mulayim ve Soran, 2002). Kitapların elektronik ortama aktarıldığı günümüzde ise Kim ve Jung (2010) ve Sun, Flores ve Tanguma (2012) e-kitapların öğretime katkılarını sorgulayan makaleler yazmışlardır. Bu bağlamda Türkiye'de de dünyada olduğu gibi okul kitapları resmi eğitimde vazgeçilmez bir unsurdur.

Nakiboğlu (2009) orta öğretim öğretmenlerinin öğretimde ders kitabı kullanımlarını araştırmıştır. Araştırmasında, öğretimin tüm aşamalarında öğretmenlerin ders kitabı kullanımının düşük seviyede olduğu belirtmektedir. Bunun sebebinin, LYS (HEPE) sınavları ile ders kitapları arasındaki uyumsuzluk olduğunu ifade etmektedir. İncikabı (2011) araştırmamıza benzer bir çalışmayı ilköğretim geometri alanı açısından yapmış ve program, ders kitapları ve SBS sınavları arasındaki uyumun önemine dikkati çekmiştir.

Araştırmamız doküman analizi biçiminde bir nitel araştırmadır. Bu çerçevede 2008-2010 arası SBS sınavları (6, 7 ve 8. sınıflar için), ders kitapları ve 2004 fen ve teknoloji dersi programı içerik açısından incelenmiştir. Araştırmamızın odak soruları şöyledir:

Türkiye'de ilköğretim biyoloji eğitimi açısından;

1. 2008-2010 SBS sınavlarında çıkan soruların dağlımı nasıldır?

2. Konu bazında ders kitaplarında geçen alıştırmalar ile programda ayrılan zaman arasında bir uyum var midır?

3. Konu bazında ders kitaplarında geçen alıştırmalar ile SBS sınavlarında çıkan sorular arasında bir uyum var midır?

4. Konu bazında programda ayrılan zaman ile SBS sınavlarında çıkan sorular arasında bir uyum var midır?

Türkiye'de 2012 yılı itibari ile 4+4+4 şeklinde 12 yıllık zorunlu eğitime geçilmiştir (MEB, 2012). Bu bağlamda, program, ders kitapları ve orta öğretime geçiş sınavları güncellenmektedir. Araştırmamızda elde edilen bulguların gelecekteki bu güncelleme çalışmalarına faydalı olacağı inancındayız.

\section{Yöntem}

Araştırmamız doküman analizi formunda nitel bir araştırmadır (Yıldırım ve Şimşek, 2011). Bu araştırmada, bahsi geçen dokümanlar iki karşılaştırmalar şeklinde karşılaştırılmıştır. illk olarak, ders kitaplarında biyoloji ünitelilerinde geçen alıştırmaların yüzdelik oranı, ilgili ünitenin programda ayrılan zamanının yüzdelik oranı ile kıyaslanmıştır. İkinci olarak, ders kitaplarında biyoloji ünitelilerinde geçen alıştırmaların yüzdelik oranı, ilgili ünitenin SBS sıvalarında çıkan sorularının yüzdelik oranı ile kıyaslanmıştır. Son olarak, biyoloji ünitelerin programda ayrılan zamanının yüzdelik oranı, ilgili ünitenin SBS sıvalarında çıkan sorularının yüzdelik oranı ile karşılaştırılmıştır. 


\section{Bulgular}

Tablo 1.

2008-2010 SBS Sınavlarında Çıkan Soruların Biyoloji Konuları Açısından Dağılımı.

\begin{tabular}{|c|c|c|c|c|c|c|}
\hline \multicolumn{2}{|l|}{ 6. Sinıf } & \multicolumn{2}{|c|}{ 7. Sinıf } & \multicolumn{2}{|c|}{ 8. Sinıf } & \multirow[b]{2}{*}{$\begin{array}{c}\text { Toplam } \\
(\%) \\
\end{array}$} \\
\hline Biyoloji konuları & $\begin{array}{l}\text { Yüzdelik } \\
\text { oranı (\%) } \\
\end{array}$ & $\begin{array}{l}\text { Biyoloji } \\
\text { konuları }\end{array}$ & $\begin{array}{c}\text { Yüzdelik } \\
\text { oranı (\%) } \\
\end{array}$ & $\begin{array}{l}\text { Biyoloji } \\
\text { konuları }\end{array}$ & $\begin{array}{c}\text { Yüzdelik } \\
\text { oranı (\%) } \\
\end{array}$ & \\
\hline Hücre & 2.1 & Sindirim sistemi & 5.6 & Mitoz & 3.1 & 14.3 \\
\hline $\begin{array}{l}\text { İnsanlarda üreme } \\
\text { büyüme ve gelişme }\end{array}$ & 4.2 & Boşaltım sistemi & 5.6 & Kalıtım & 6.2 & 16 \\
\hline $\begin{array}{l}\text { Hayvanlarda üreme } \\
\text { büyüme ve gelişme }\end{array}$ & 6.3 & $\begin{array}{l}\text { Denetleyici ve } \\
\text { düzenleyici } \\
\text { sistemler }\end{array}$ & 3.7 & Mayoz & - & 10 \\
\hline $\begin{array}{l}\text { Çiçekli bitkilerde } \\
\text { üreme büyüme ve } \\
\text { gelişme }\end{array}$ & 6.3 & $\begin{array}{l}\text { Duyu } \\
\text { organlarımız }\end{array}$ & 7.4 & $\begin{array}{l}\text { DNA ve genetik } \\
\text { kod }\end{array}$ & 1.5 & 15.2 \\
\hline $\begin{array}{l}\text { Destek ve hareket } \\
\text { sistemi }\end{array}$ & 4.2 & Ekosistemler & 5.6 & $\begin{array}{l}\text { Adaptasyon ve } \\
\text { evrim }\end{array}$ & 4.6 & 14.4 \\
\hline Solunum Sistemi & - & $\begin{array}{l}\text { Türkiye'de } \\
\text { biyoçeşitlilik }\end{array}$ & - & $\begin{array}{l}\text { Besin zinciri ve } \\
\text { enerji akışı }\end{array}$ & 12.3 & 12.3 \\
\hline \multirow[t]{4}{*}{ Dolaşım Sistemi } & 8.3 & $\begin{array}{l}\text { Çevre sorunları } \\
\text { ve etkileri }\end{array}$ & 5.6 & Madde döngüleri & 1.5 & 15.4 \\
\hline & & & & Geri dönüşüm & 1.5 & 1.5 \\
\hline & & & & Yenilenebilir ve & & \\
\hline & & & & $\begin{array}{l}\text { Yenilenemez } \\
\text { enerji kaynakları }\end{array}$ & 1.5 & 1.5 \\
\hline Toplam (\%): & 34.9 & & 33.5 & & 30.7 & \\
\hline
\end{tabular}

http://oges.meb.gov.tr/sbs/ adresinden edinilmiştir.

Tablo 1, bize 2008-2010 yılları arasında SBS sınavlarında çıkan soruların biyoloji ünitelerine göre dağılımını vermektedir. Araştırmamıza 2008-2010 yılları arasındaki SBS sınavlarının dâhil edilmesinin ana sebebi bu yılar arasında 6, 7 ve 8. sınıfların tamamına uygulanmış olmasıdır. SBS sınavlarında en fazla soru çıkan konulara baktığımızda; 6. sınıfta "dolaşım sistemi", 7. sınıfta "duyu organlarımız", 8. sınıfta "besin zinciri ve enerji akışı" olduğunu görmekteyiz. İkili kıyaslamalar aşağıda verilmiştir.

\section{Program-Ders Kitabı Karşılaştırması}

Tablo 2.

2008-2010 Öğretim Yıllarında Fen ve Teknoloji Ders Kitaplarındaki Biyoloji Konularında Kullanılan Alıştırmalar ile Programda Önerilen Zamanların Yüzdelik Oranları.

\begin{tabular}{lrrrrrr}
\hline & \multicolumn{2}{c}{ 6. Sınıf } & \multicolumn{2}{c}{ 7. Sınıf } & \multicolumn{2}{c}{ 8. Sınıf } \\
\hline Öğrenme alanı & Ayrılan Zaman & Alıştırma & Ayrılan Zaman & Alıştırma & Ayrılan Zaman & Alıştırma \\
\hline Canlılar ve hayat* & 30.4 & 23.8 & 32 & 34.4 & 27.8 & 29.4 \\
Madde ve değiş̧im & 30.5 & 23.8 & 25 & 14 & 34.7 & 23.5 \\
Fiziksel olaylar & 29.4 & 34 & 33.3 & 38.4 & 29.2 & 34 \\
Dünya ve evren & 9.7 & 18.4 & 9.7 & 13.2 & 8.3 & 13.1 \\
\hline
\end{tabular}

* Bu öğrenme alanı "Biyoloji" olarak değerlendirilmiştir.

Tablo 2 de, 2006 fen ve teknoloji programında biyoloji ile ilgili öğrenme alanını kapsayan konularda önerilen süreler ile ders kitaplarındaki ilgili konularda yer alan alıştırmaların yüzdelik oranları kıyaslanmıştır. 7. sınıf "madde ve değişim" ve 6. sınıf "dünya ve evren” öğrenme alanı açısından program 
ve ders kitapları arasında önemli bir fark gözükmektedir. Diğer öğrenme alanlarında ise program ve ders kitapları arasında bir uyum olduğu söylenebilir.

\section{Ders Kitabı-Sınavlar Karşılaştırması}

Tablo 3.

2008-2010 Öğretim Yıllarında Fen ve Teknoloji Ders Kitaplarındaki Biyoloji Konularında Kullanılan Alıştırmalar ile Sınavlarda Çıkan Soruların Yüzdelik Oranları.

\begin{tabular}{lrrrrrr}
\hline & \multicolumn{2}{c}{ 6. Sınıf } & \multicolumn{2}{c}{ 7. Sınıf } & \multicolumn{2}{c}{ 8. Sınıf } \\
\hline Öğrenme alanı & Alıştırma & $\begin{array}{r}\text { Sınav } \\
\text { Soruları }\end{array}$ & Alıştırma & $\begin{array}{r}\text { Sınav } \\
\text { Soruları }\end{array}$ & Alıştırma & $\begin{array}{r}\text { Sınav } \\
\text { Soruları }\end{array}$ \\
\hline Canlılar ve hayat* & 23.8 & 31.2 & 34.4 & 33.3 & 29.4 & 33.8 \\
Madde ve değişim & 23.8 & 31.2 & 14 & 27.8 & 23.5 & 27.7 \\
Fiziksel olaylar & 34 & 31.3 & 38.4 & 33.3 & 34 & 35.4 \\
Dünya ve evren & 18.4 & 6.3 & 13.2 & 5.6 & 13.1 & 3.1 \\
\hline
\end{tabular}

* Bu öğrenme alanı "Biyoloji" olarak değerlendirilmiştir.

Tablo 3 de, biyoloji ile ilgili öğrenme alanını kapsayan konularda ders kitaplarında yer alan alıştırmaların yüzdelik oranlarını ile 2008-2010 yılları arasında SBS sınavlarında çıkan soruların yüzdelik oranları kıyaslanmıştır. "dünya ve evren” öğrenme alanı açısından ders kitabı ve SBS sınavlarında çıkan sorular arasında kayda değer bir fark gözükmektedir. Ders kitaplarında önemli oranda alıştırma yer almasına rağmen SBS sınavlarında aynı oranda "dünya ve evren" öğrenme alanından soru çıkmamıştır. $\mathrm{Bu}$, bir uyumsuzluk olarak gözükmektedir.

\section{Program-Sınavlar Karşılaştırması}

Tablo 4.

Programdaki Biyoloji Konularına Ayrılan Zaman ile 2008-2010 Yıllarında Sınavlarda Çıkan Soruların Yüzdelik Oranları.

\begin{tabular}{lrrrrrr}
\hline & \multicolumn{2}{c}{ 6. Sınıf } & \multicolumn{2}{c}{ 7. Sınıf } & \multicolumn{2}{c}{ 8. Sınıf } \\
\hline Öğrenme alanı & $\begin{array}{c}\text { Ayrılan } \\
\text { Zaman }\end{array}$ & $\begin{array}{r}\text { Sınav } \\
\text { Soruları }\end{array}$ & $\begin{array}{c}\text { Ayrılan } \\
\text { Zaman }\end{array}$ & $\begin{array}{r}\text { Sınav } \\
\text { Soruları }\end{array}$ & $\begin{array}{r}\text { Ayrılan } \\
\text { Zaman }\end{array}$ & $\begin{array}{r}\text { Sınav } \\
\text { Soruları }\end{array}$ \\
\hline Canlılar ve hayat* & 30.4 & 31.2 & 32 & 33.3 & 27.9 & 33.8 \\
Madde ve değişim & 30.5 & 31.2 & 25 & 27.8 & 34.7 & 27.7 \\
Fiziksel olaylar & 29.4 & 31.3 & 33.3 & 33.3 & 29.1 & 35.4 \\
Dünya ve evren & 9.7 & 6.3 & 9.7 & 5.6 & 8.3 & 3.1 \\
\hline
\end{tabular}

* Bu öğrenme alanı "Biyoloji" olarak değerlendirilmiştir.

Tablo 4 de, biyoloji ile ilgili öğrenme alanını kapsayan konularda programda önerilen süreler ile 20082010 SBS sınavlarında çıkan soruların yüzdelik oranları kıyaslanmıştır. "dünya ve evren" öğrenme alanında 8. sınıfta programda önemli oranda zaman ayrılmış iken SBS sınavlarında aynı oranda soru çıkmadığını görmekteyiz. Bu, program ve SBS sınavları arasında bir uyumsuzluk olarak düşünülebilir.

Tablo 5 de, 2008-2010 yıları arasında SBS sınavlarında hiç soru çıkmayan biyoloji konuları gösterilmiştir. Ders kitapları ve programda önemli oranda yer alan bu konularda SBS sınavlarında hiç soru çıkmamış olması makalemizin ele aldığı üç unsur (program-ders kitapları-SBS sınavları) arasında bir uyumsuzluk olarak görülmektedir. 
Tablo 5.

2008-2010 SBS Sınavlarında Hiç Soru Çıkmayan Biyoloji Konuları.

\begin{tabular}{llrrr}
\hline \multirow{2}{*}{ Sınıf } & \multirow{2}{*}{ Konular } & \multicolumn{2}{c}{ Yüzdelik oran (\%) } \\
\cline { 3 - 4 } & & Ders kitabı & Program & Test \\
\hline 6 & Solunum sistemi & 3.4 & 4.6 & 0 \\
7 & Türkiye'de biyoçeşitlilik & 2.6 & 3.7 & 0 \\
8 & Mayoz & 2 & 3.5 & 0 \\
\hline
\end{tabular}

\section{Sonuç, Tartışma ve Öneriler}

İkili karşılaştırmalarda, makalemizde karşılaştırılan üç değişken arasında (program, yerleştirme sınavları ve ders kitapları) genel anlamda bir uyumun olduğu söylenebilir. 2008-2010 yılları arasında SBS sınavlarında yaklaşık üçte bir oranında biyoloji sorularının çıktığını görmekteyiz. Araştırmamız resmi program, resmi ders kitapları ve orta öğretime geçiş sınavı evrakları ile sınırlıdır. Bu dokümanların uygulamadaki farklı kullanımları değerlendirme dışı bırakılmıştır. Örneğin resmi ilköğretim ikinci kademe fen ve teknoloji dersi öğretim programı içerisinde yer alan etkinlikler fen öğretmenleri tarafından uygulamada kullanılmamış veya farklı biçimlerde kullanılmış olabilir.

Türkiye'deki en son öğretim programı değişikliği öğretmen eğitiminde de değişikliğe gidilmesini gerekli kılmıştır. Ancak, araştırmalar göstermektedir ki öğretmenler yeni program hakkında yeterli bilgiye sahip değillerdir (Özden, 2007; Tekbıyık ve Akdeniz, 2008) veya uygulamada çok fazla kullanmamaktadırlar (Karaer, 2006). Aynı zamanda programın uygulama sürecinde alt yapı ve zaman sorunları yaşamaktadırlar (Aydın, 2007; Bulut, 2005). Sonuç olarak programın uygulamasında karşılaşılan sorunlar ve öğretmen eğitimi eksikliği yeni program reformunun verimliliğini azaltan unsurlardır.

Ders kitaplarında ve programda yer almasına rağmen üç konuda (Solunum sistemi, Türkiye'de biyoçeşitlilik ve Mayoz) 2008-2010 yılları arasında SBS de hiç soru çıkmamış olması bir uyumsuzluk olarak görülebilir. Son yıllarda fotosentez konusu üzerine birçok araştırma yapılmıştır (Brown ve Schwartz, 2009; Cañal, 1999; Griffard ve Wandersee, 2001; Käpylä, Heikkinen ve Asunta, 2009; Kral, Lott ve Wymer, 2009; Lin ve Hu, 2003; Marmaroti ve Galanopoulou, 2006; Piper ve Shaw, 2010; Yenilmez ve Tekkaya, 2006). Bu, tüm dünyada bu konunun öğretimine verilen önemin bir göstergesi sayılabilir. Fotosentez ile ilgili ciddi oranda SBS de soru çıkması (12,3\%), Türkiye'de de bu konuya verilen önemi göstermektedir. Ancak, 8. sınıf mayoz konusu, orta öğretim programda yer alan kalıtım konularının alt yapısını oluşturması açısından önem arz etmektedir. Bu konuda, 2008-2010 yılları arasında SBS de hiç soru çıkmamış olması bu açıdan önemli bir eksiklik olarak düşünülebilir.

Ulusal ve uluslararası sınavlarda (TIMSS, PISA) Türk öğrenciler fen alanında düşük başarı sergilemektedirler (Ulusal Rapor, 2011). Bu sebeple, gelecekteki araştırmalarda hedeflenen kazanımlar ve öğretim etkinliklerinin uygulamadaki eksikliklerinin veya başarıya yansımama nedenlerinin araştırılması bir ihtiyaç olarak görülmektedir. Ayrıca, araştırmamıza dâhil etmediğimiz öğretmen kılavuz kitapları ve öğrenci çalışma kitaplarının da yeni araştırmalarca incelenmesi faydalı olacaktır. 


\section{Kaynaklar}

Abd-El-Khalick, F., Waters, M., \& Le, A. P. (2008). Representations of nature of science in high school chemistry textbooks over the past four decades. Journal of Research in Science Teaching, 45(7), 835855.

Akınoğlu, O. (2008). Primary education curriculum reforms in Turkey. Wold Applied Sciences Journal, 3 (2), 195-199.

Akşit, N. (2007). Educational reform in Turkey. International Journal of Educational Development, 27 (2), 129-137.

Aydın, O. (2007). Teacher views on primary 4th and 5th grade science and technology course curriculum (A case of Kütahya). Unpublished master's thesis, University of Osmangazi, Eskişehir.

Babadoğan, C., \& Olkun, S. (2006). Program development models and reform in Turkish primary school mathematics curriculum. International Journal for Mathematics Teaching and Learning, 1(1), 1-6.

Bayrakçı, M. (2005). Ders kitapları konusu ve ilköğretimde ücretsiz ders kitabı dağıtımı projesi. Milli Eğitim Dergisi, 165. Retrieved June 21, 2012, from http:// dhgm.meb.gov.tr/ yayimlar/ dergiler /Milli_Egitim_Dergisi /165/bayrakci.htm.

Beaton, A. E., Martin, M. O., Mullis, I. V., Gonzales, E. J., Smith, T. A., \& Kelly, D. L. (1996). Science achievement in the middle school years: IEA's Third International Mathematics and Science Study (TIMSS). Chestnut Hill, MA: Center for the Study of Testing, Evaluation, and Educational Policy, Boston College.

Bishop, J. H. (1998). The effect of curriculum-based external exit exam systems on student achievement. The Journal of Economic Education, 29(2), 171-182.

Brown, M. H., \& Schwartz, R. S. (2009). Connecting photosynthesis and cellular respiration: Preservice teachers' conceptions. Journal of Research in Science Teaching, 46(7), 791-812.

Bulut, M. (2005). Curriculum reform in Turkey: A case of primary school mathematics curriculum. www.ejmste.com, 203(3), 203-212.

Cañal, P. (1999). Photosynthesis and 'inverse respiration' in plants: An inevitable misconception? International Journal of Science Education, 21(4), 363-371.

Chiappetta, E. L., \& Fillman, D. A. (2007). Analysis of five high school biology textbooks used in the United States for inclusion of the nature of science. International Journal of Science Education, 29(15), 1847-1868.

de Posada, J. M. (1999). The presentation of metallic bonding in high school science textbooks during three decades: Science educational reforms and substantive changes of tendencies. Science education, 83(4), 423-447.

Delil, H. (2006). An analysis of geometry problems in 6 - 8 grades Turkish mathematics textbooks. Unpublished doctoral dissertation, Middle East Technical University, Ankara.

Demirbaş, M. (2008). A comparative study on 6th grade "science curriculum" and "science and technology curriculum": Pre-instructional views. Uludag University, Faculty of Education Journal, 21(2), 313-338.

Dindar, H. \& Taneri, A. (2011). Comparing goals, concepts and activities of science programs developed by the Turkish ministry of education in 1968, 1992, 2000 and 2004. Kastamonu University, Kastamonu Education Journal, 19(2), 363-378

Gözütok, F. D. (2003). Curriculum development in Turkey. In W.F. Pinar (Eds.). International Handbook of Curriculum Research (pp. 607-622). Routledge: London.

Griffard, P. B., \& Wandersee, J. H. (2001). The two-tier instrument on photosynthesis: What does it diagnose?. International Journal of Science Education, 23(10), 1039-1052. 
Grossman, G. M., Onkol, P. E., \& Sands, M. (2007). Curriculum reform in Turkish teacher education: Attitudes of teacher educators towards change in an EU candidate nation. International Journal of Educational Development, 27(2), 138-150.

Güneş, M.H., Çelikler, D. \& Gökalp, M. (2008). İlköğretim I. kademedeki yeni fen ve teknoloji ders kitapları konusunda sınıf öğretmenlerinin görüşleri. Çukurova Üniversitesi, Sosyal Bilimler Enstitüsü Dergisi, 17(3), 193-210.

HEPE., (2010). 2010-LYS sınavlarına ilişkin sayısal bilgiler (sunu). Ankara: OSYM. http://www.osym.gov.tr/dosya/1-55969/h/lyssonuc2010sunum.pps (Accesssed 20 November 2012).

İcbay, M. A. (2005). A SWOT Analysis on the university entrance examination in Turkey: A case study. Mersin University Journal of the Faculty of Education, 1(1), 126-140.

Incikabı, L. (2011). The coherence of the curriculum, textbooks and placement examinations in geometry education: How reform in Turkey brings balance to the classroom. Education as Change, 15(2), 239255.

İrez, S. (2009). Nature of science as depicted in Turkish biology textbooks. Science Education, 93(3), 422447.

Käpylä, M., Heikkinen, J. P., \& Asunta, T. (2009). Influence of content knowledge on pedagogical content knowledge: The case of teaching photosynthesis and plant growth. International Journal of Science Education, 31(10), 1395-1415.

Karaer, H. (2006). Opinions of science course teachers about the subject teaching in primary school (Amasya sample). Erzincan Journal of Education, 8(2), 97-111.

Kim, J. H. Y., \& Jung, H. Y. (2010). South Korean digital textbook project. Computers in the Schools, 27(34), 247-265.

Knain, E. (2001). Ideologies in school science textbooks. International Journal of Science Education, 23(3), 319-329.

Koç, Y., Işıksal, M., \& Bulut, S. (2007). Elementary school curriculum reform in Turkey. International Education Journal, 8(1), 30-39.

Krall, R. M., Lott, K. H., \& Wymer, C. L. (2009). Inservice elementary and middle school teachers' conceptions of photosynthesis and respiration. Journal of Science Teacher Education, 20(1), 41-55.

Leite, L. (1999). Heat and temperature: An analysis of how these concepts are dealt with in textbooks. European Journal of Teacher Education, 22(1), 75-88.

Lemoni, R., Stamou, A. G., \& Stamou, G. P. (2011). "Romantic", "Classic” and "Baroque” Views of Nature: An Analysis of Pictures About the Environment in Greek Primary School Textbooks-Diachronic Considerations. Research in Science Education, 41(5), 811-832.

Lin, C. Y., \& Hu, R. (2003). Students' understanding of energy flow and matter cycling in the context of the food chain, photosynthesis, and respiration. Int. J. Sci. Educ., 25(12), 1529-1544.

Lubben, F., Campbell, B., Kasanda, C., Kapenda, H., Gaoseb, N., \& Kandjeo-Marenga, U. (2003). Teachers' Use of Textbooks: Practice in Namibian science classrooms. Educational studies, 29(2-3), 109-125.

Marmaroti, P., \& Galanopoulou, D. (2006). Pupils' understanding of photosynthesis: A questionnaire for the simultaneous assessment of all aspects. International Journal of Science Education, 28(4), 383403.

Martin, M. O., Mullis, I. V., \& Foy, P. (2008). TIMSS 2007 international mathematics report: Findings from IEA's Trends in International Mathematics and Science Study at the fourth and eighth grades. IEA.

Martin, M. O., Mullis, I. V., Gonzales, E. J., \& Chrostowski, S. J. (2004). TIMSS 2003 international science report: Findings from IEA's trends in international mathematics and science study at the fourth and eighth grades. TIMSS \& PIRLS International Study Center, Lynch School of Education, Boston College. 
Martin, M. O., Mullis, I. V., Gonzalez, E. J., Gregory, K. D., Smith, T. A., Chrostowski, S. J., ... \& O’Connor, K. M. (2000). TIMSS 1999 international science report. Findings from IEA's Repeat of the Third International Mathematics and Science Study at the Eighth Grade. Chestnut Hill, MA: Boston College.

MONE, (2006). ilköğretim fen ve teknoloji dersi (6-8 sınıflar) öğretim programı [Elementary school science curriculum (grades 6-8)]. Retrieved December 20, 2011, from http://ttkb.meb.gov.tr/program2.aspx/?width=900.

MONE, (2011). National education statistics: Formal education 2010-2011. Ankara: Milli Eğitim Basımevi.

MONE, (2012). 12 Yıllık Zorunlu Eğitime Yönelik Uygulamalar GENELGE2012/20. Retrieved April 20, 2013, from http://mevzuat.meb.gov.tr/html/onikiyillik/oniki.html.

Mülayim, H., \& Soran, H. (2002). Lise 1 biyoloji ders kitapları ve haftalık ders saatleri hakkında öğrenci, öğretmen ve okul yöneticilerinin görüş ve önerileri. Hacettepe Üniversitesi Eğitim Fakültesi Dergisi, 23, 185-197.

Nakiboğlu, C. (2009). Deneyimli kimya öğretmenlerinin ortaöğretim kimya ders kitaplarını kullanımlarının incelenmesi. Ahi Evran Üniversitesi Kırşehir Eğitim Fakültesi Dergisi, 10(1), 91-101.

Niaz, M. (1998). From cathode rays to alpha particles to quantum of action: A rational reconstruction of structure of the atom and its implications for chemistry textbooks. Science Education, 82(5), 527552.

Özden, M. (2007). Problems with science and technology education in Turkey. Eurasia Journal of Mathematics, Science \& Technology Education, 3(2), 157-161.

Öztürk, i. H. (2011). Curriculum reform and teacher autonomy in Turkey: The case of the history teaching. International journal of instruction, 4(2), 113-128.

Piper, S., \& Shaw Jr, E. L. (2010). Teaching Photosynthesis with ELL Students. Science Activities, 47(3), 6874.

Rillero, P. (2010). The rise and fall of science education: A content analysis of science in elementary reading textbooks of the 19th century. School Science and Mathematics, 110(5), 277-286.

Roseman, J. E., Stern, L., \& Koppal, M. (2010). A method for analyzing the coherence of high school biology textbooks. Journal of Research in Science Teaching, 47(1), 47-70.

SEPE., (2010). 2010 Seviye Belirleme Sınavı Istatistikleri (The statistics for 2010 secondary education institutions student selection and placement examination). Retrieved December 20, 2011, from http://oges.meb.gov.tr/sbs_istat.htm.

Sun, J., Flores, J., \& Tanguma, J. (2012). E-Textbooks and students' learning experiences. Decision Sciences Journal of Innovative Education, 10(1), 63-77.

Tekbıyık, A. \& A.R. Akdeniz. (2008). Teachers' views about adoption and application of primary science and technology curriculum. Necatibey Faculty of Education Electronic Journal of Science and Mathematics Education, 2(2), 23-37.

Tracana, R. B., Carvalho, G. S., Ferreira, C., \& Ferreira, M. E. (2008). Analysing the theme of pollution in Portuguese geography and biology textbooks. International Research in Geographical and Environmental Education, 17(3), 199-211.

Ulusal Rapor. (2011). TIMSS 2007 ulusal matematik ve fen raporu 8. sınıflar. T.C. Milli Eğitim Bakanlığı EARGE. Retrieved April 12, 2012, from http://earged.meb.gov.tr/dosyalar/dokumanlar/uluslararasi/ timss_2007_ulusal_raporu.rar.

Ünal, S., Coştu B. \& Karataş, F.O. (2004). A general look at the science curriculum development studies in Turkey. Gazi University, Faculty of Education Journal, 24(2), 183-202.

Uzun, S., Bütüner, S.Ö. \& Yiğit, N. (2010). A comparison of the results of TIMSS 1999-2007: The most successful five countries-Turkey sample. Illköğretim-Online, 9(3), 1174-1188. 
van Eijck, M., \& Roth, W. M. (2008). Representations of scientists in Canadian high school and college textbooks. Journal of Research in Science Teaching, 45(9), 1059-1082.

Wilkinson, J. (1999). A quantitative analysis of physics textbooks for scientific literacy themes. Research in Science Education, 29(3), 385-399.

Yang, D. (2011). A comparison of content in syllabus-based senior geography textbooks and standardsbased senior geography textbooks in mainland China. International Research in Geographical and Environmental Education, 20(2), 121-138.

Yenilmez, A., \& Tekkaya, C. (2006). Enhancing students' understanding of photosynthesis and respiration in plant through conceptual change approach. Journal of science Education and Technology, 15(1), 81-87.

Yıldırım, A., \& Şimşek, H. (2005). Sosyal bilimlerde nitel araştırma yöntemleri (7 ${ }^{\text {th }}$ ed.). Ankara: Seçkin Yayıncılık. 